\title{
PENGARUH PEMBERIAN NUTRISI KERANG DARAH Anadara granosa L. TERHADAP TINGKAT KEPADATAN SPERMATOZOA MENCIT Mus musculus L.
}

\section{THE EFFECT OF FEEDING BLOOD COCKLE Anadara granosa L. ON THE SPERMATOZOA DENSITY OF Mus musculus $L$.}

\author{
Ridha Nirmalasari \\ Jurusan PMIPA, IAIN Palangka Raya \\ Email : ridha.nirmalasari@gmail.com
}

\begin{abstract}
Abstrak
Telah dilakukan penelitian mengenai pengaruh pemberian nutrisi kerang darah Anadara granosa L. terhadap tingkat kepadatan spermatozoa mencit Mus musculus L. Tujuan penelitian adalah untuk melihat pengaruh pemberian nutrisi kerang darah $A$. granosa terhadap tingkat kepadatan spermatozoa mencit $M$. musculus. Penelitian ini menggunakan hewan uji mencit $M$. musculus jantan dewasa dengan umur 8-10 minggu yang diberi pakan kerang darah $A$. granosa berupa pelet selama 21 hari. Spermatozoa diambil dari cauda epididimis dan selanjutnya diencerkan dengan $\mathrm{NaCl}$ fisiologis, kemudian diamati dan dihitung dengan menggunakan haemocytometer. Hasil penelitian menunjukkan bahwa pemberian nutrisi kerang darah $A$. granosa, L. sebagai pakan mencit M. musculus, L. dapat meningkatkan kepadatan spermatozoa, terlihat dari adanya peningkatan tingkat kepadatan rerata spermatozoa pada mencit kontrol $105,25 \times 10^{4}$ $\mathrm{sel} / \mathrm{ml}$, sedangkan tingkat kepadatan rerata spermatozoa pada mencit yang diberi kerang $115,3 \times 10^{4} \mathrm{sel} / \mathrm{ml}$. Ini berdasarkan hasil analisis data dengan Uji $\mathrm{F}$ pada tingkat kepercayaan $95 \%$ menyatakan terdapat korelasi yang bersifat positif dan signifikan.
\end{abstract}

Kata Kunci : Spermatozoa, Tingkat kepadatan, Kerang darah Anadara granosa, L., Mencit Mus musculus, L.

\section{Abstract}

Research about the Effect of feeding blood cockle Anadara granosa $L$ on the spermatozoa density Of Mus musculus L. has been done. The purpose of this research was to know the effect of feeding blood cockle Anadara granosa $L$ on the spermatozoa density Of Mus musculus $\mathrm{L}$. The 8-10 weeks age, male mice $M$. musculus feeding with blood cockle $A$. granosa for 21 days. Sperm collected from cauda of epididimys and then observed and counted using haemocytometer. The result showed that feeding with blood cockle $A$. granosa to mice $M$. musculus could increase the density of its spermatozoa. It showed from increase the density of its spermatozoa from 105,25 $\times 10^{4} \mathrm{sel} / \mathrm{ml}$ sperm in control group become $115,3 \times 10^{4} \mathrm{sel} / \mathrm{ml}$ sperm in treatment group by use of $\mathrm{F}$ test. Fidelity guarantee 95 percent explain that there are positive correlation and significant.

Keyword : Sperm, Density, Blood cockle Anadara granosa, L., Mice Mus musculus, L. 


\section{Pendahuluan}

Indonesia merupakan Negara bahari yang tiga perempat wilayahnya adalah perairan. Luas lautan mencapai 5,8 juta $\mathrm{km}^{2}$ dengan garis pantai sepanjang $81.000 \mathrm{~km}$. Di dalam wilayah lautan Indonesia yang begitu luas tersimpan potensi sumber daya alam yang sangat besar, termasuk di dalamnya sumber daya perikanan seperti ikan, udang, dan kerang (Furkon, 2012).

Pertambahan penduduk Indonesia berdampak terhadap peningkatan kebutuhan gizi untuk meningkatkan mutu kesehatan. Sumber asupan gizi terbaik tentu saja berasal dari bahan alami seperti kerang. Diperkirakan terdapat sekitar 1000 jenis kerang yang hidup di perairan Indonesia (Nontji, 2012). Banyak jenis kerang yang dapat dikonsumsi dan sebagian telah dibudidayakan. Jenis kerang Anadara yang paling populer di Indonesia salah satunya adalah kerang darah $A$. granosa. Seluruh bagian tubuh yang lunak dapat dimakan, sedang cangkangnya dapat digunakan sebagai bahan pembuat jalanan dan sebagai campuran makanan ternak unggas (Suwignyo, 2005).

Kandungan gizi yang terdapat pada kerang tidak jauh berbeda dengan biota laut lainnya. Kerang mengandung zat-zat mineral yang dibutuhkan oleh tubuh, seperti besi $(\mathrm{Fe})$, fosfor $(\mathrm{P})$, flour $(\mathrm{F})$, iodium $(\mathrm{I})$, kalsium $(\mathrm{Ca})$, kalium $(\mathrm{K})$, seng $(\mathrm{Zn})$, dan selenium (Se). Disamping itu, kerang merupakan sumber protein hewani yang tergolong dalam Complete Protein, karena kadar asam amino esensialnya tinggi (85\%-95\%) dan mudah dicerna oleh tubuh. Kerang juga mengandung vitamin yang larut dalam lemak serta B kompleks (Furkon, 2012).

Infertilitas merupakan salah satu gangguan dalam kesehatan reproduksi. Infertilitas didefinisikan sebagai ketidakmampuan untuk menghasilkan konsepsi setelah hubungan teratur tanpa menggunakan alat kontrasepsi selama satu tahun. Hampir 30\% penyebab infertilitas adalah gangguan produksi sperma, gangguan fungsi sperma, dan gangguan transportasi sperma (World Health Organization, 1999).

Faktor yang sangat penting dan dapat dikendalikan untuk mengatasi masalah infertilitas adalah pola makan dan gaya hidup. Mengkonsumsi kerang merupakan salah satu alternatif untuk meningkatkan kualitas spermatozoa. Hal ini disebabkan karena kandungan nutrisi pada kerang sangat tinggi.

Berdasarkan hasil penelitian, kandungan nutrisi pada kerang berperan dalam produksi dan viabilitas, mencegah degradasi, dan stabilisasi membran spermatozoa (Lewis, 1996).

Oleh karena itu, mengingat pentingnya kandungan gizi yang terdapat pada kerang maka perlu dilakukan penelitian tentang pengaruh pemberian nutrisi kerang darah Anadara granosa terhadap tingkat kepadatan spermatozoa mencit Mus musculus.

\section{Bahan dan Metode}

\section{Waktu dan Tempat Penelitian}

Penelitian ini dilakukan di Makassar. Adapun pemeliharaan hewan mencit Mus musculus dilakukan di kandang hewan, fakutas peternakan Unhas, pengambilan bahan kerang darah Anadara granosa dilakukan di kabupaten Bulukumba, dan pengamatan sperma mencit dilakukan di laboratorium biologi,UNM. 


\section{Alat dan Bahan}

Alat-alat yang digunakan dalam penelitian ini adalah kompor, panci, baskom, sendok, pisau, gunting, nampan, kandang mencit, gelas arloji, batang pengaduk, baki bedah, dissecting set, pipet tetes, pipet skala, lumpang porselin, neraca analitik, haemocytometer, kaca penutup, mikroskop perbesaran 400 kali, hand counter, dan botol sampel. Bahan-bahan yang digunakan dalam penelitian ini adalah kerang darah Anadara granosa, hewan uji mencit Mus musculus, sperma mencit, eter, $\mathrm{NaCl}$ fisiologis $0,9 \%$, alkohol $70 \%$, air suling, kapas, plastik, karet gelang, jarum pentul, sarung tangan, kertas label dan tissue roll.

\section{Metode Penelitian}

\section{a. Pemeliharaan Hewan Uji}

Hewan uji yang digunakan adalah mencit $M$. musculus jantan dewasa dengan umur 8-10 minggu dan berat badan rata-rata 23-29 gram sebanyak 8 ekor. Hewan uji ditempatkan di dalam 2 kandang, masing-masing kandang 4 ekor. Kandang berbentuk kotak, terbuat dari bahan fiber dengan ukuran $35 \mathrm{~cm} \times 20 \mathrm{~cm} \times 17 \mathrm{~cm}$, kemudian diberi alas berupa serbuk kayu secukupnya, yang dibersihkan setiap 2 kali seminggu. Kotak tersebut diberi tutup yang terbuat dari besi untuk tempat makanan dan botol minuman. 8 ekor mencit tersebut diadaptasikan pada tempat dan kondisi yang homogen (temperatur, suhu) selama 7 hari sebelum perlakuan. Selama adaptasi, 8 ekor mencit M. Musculus diberikan pakan AD2 dan air PAM.

\section{b. Pengambilan dan Pengolahan Kerang Darah Anadara granosa, L.}

Kerang yang digunakan adalah kerang darah $A$. granosa segar yang dibeli dari Pasar Cekkeng, Jl. Sultan Hasanuddin, Kabupaten Bulukumba, Sulawesi Selatan. Kerang darah $A$. granosa yang diberikan selama perlakuan pada mencit berupa pelet. Kerang yang masih segar ditempatkan di dalam baskom dan dicuci sampai bersih, kemudian direbus dengan air hingga cangkangnya terbuka. Setelah itu, bagian tubuh yang lunak yang berada didalam cangkang dikeluarkan kemudian dijemur di bawah sinar matahari hingga kering. Dicabik-cabik, kemudian dihancurkan dengan cara ditumbuk dengan menggunakan lumpang porselin hingga halus, dicampurkan dengan pakan AD2 sebagai perekat dengan perbandingan kerang darah $A$. granosa dan AD2 adalah 3:1.

Pemberian Nutrisi Anadara granosa, L

Perlakuan hewan uji mencit $M$. musculus dibagi menjadi 2 kelompok. Kelompok I sebagai kontrol, mencit $M$. musculus diberikan pakan AD2 dan air PAM dua kali sehari (pagi dan sore) setiap hari, selama 21 hari. Kelompok II sebagai perlakuan, yaitu diberikan kerang darah $A$. granosa yang berupa pelet sebanyak 20-30 gram dan air PAM dua kali sehari (pagi dan sore) setiap hari, selama 21 hari.

\section{c. Pengeluaran Spermatozoa Mencit Mus musculus, L.}

Pengambilan spermatozoa mencit dilakukan dengan pembedahan. Sebelum dibedah, mencit dinarkose dengan menggunakan eter. Bagian abdominal dibedah, lalu diambil salah satu testis, kemudian spermatozoa diperoleh dari bagian cauda epididimis. Epididimis dibersihkan dengan alkohol $70 \%$, kemudian dimasukkan ke dalam gelas arloji yang berisi $1 \mathrm{ml} \mathrm{NaCl}$ fisiologis, dipotong-potong dengan gunting kecil hingga halus dan diaduk dengan batang pengaduk, hingga membentuk suspensi spermatozoa. Suspensi spermatozoa pada setiap hewan uji mencit ditempatkan pada botol sampel yang berbedabeda. 
d. Pengamatan Tingkat Kepadatan Spermatozoa Mencit Mus musculus, L.

Penghitungan tingkat kepadatan spermatozoa dilakukan dengan cara, suspensi sperma yang telah ditempatkan pada botol sampel diambil dengan menggunakan pipet tetes, kemudian diteteskan pada haemocytometer, ditutup dengan kaca penutup, kemudian diamati di bawah mikroskop dengan perbesaran 400 kali. Hasil penghitungan merupakan tingkat kepadatan spermatozoa dalam $10^{4} \mathrm{sel} / \mathrm{ml}$ suspensi spermatozoa.

\section{e. Analisis Data}

Analisis spermatozoa dilakukan dengan membandingkan jumlah spermatozoa dari 2 perlakuan, yaitu (1) 4 ekor mencit tanpa perlakuan/kontrol dan (2) 4 ekor mencit yang diberikan tauge secara teratur setiap hari selama 21 hari. Hasil studi kasus-kontrol yaitu dengan menggunakan analisis Uji $\mathrm{F}$ untuk melihat ada atau tidaknya pengaruh pemberian nutrisi kerang darah Anadara granosa, L. terhadap tingkat kepadatan spermatozoa mencit M. musculus, L.

\section{Hasil dan Pembahasan}

Dari Tabel I terlihat bahwa pemberian nutrisi kerang darah memberikan pengaruh terhadap peningkatan tingkat kepadatan spermatozoa mencit $M$. musculus, L. Terjadi peningkatan rata-rata tingkat kepadatan dari $10,5,25 \times 10^{4} \mathrm{sel} / \mathrm{ml}$ sperma pada kelompok kontrol menjadi $115,3 \times 10^{4} \mathrm{sel} / \mathrm{ml}$ sperma pada kelompok perlakuan sehingga dari uji statistik dengan nilai $\alpha 0,01$ menyatakan terdapat korelasi yang bersifat positif dan signifikan artinya ada pengaruh antara pemberian nutrisi Anadara granosa, L. terhadap tingkat kepadatan spermatozoa mencit M. Musculus, L.

Tabel I. Tingkat kepadatan spermatozoa mencit M. musculus, L. pada kelompok kontrol dan perlakuan $\left(\ldots \times 10^{4} \mathrm{sel} / \mathrm{ml}\right)$

\begin{tabular}{|c|c|c|c|c|c|c|}
\hline & \multicolumn{4}{|c|}{ Ulangan } & \multirow{2}{*}{$\begin{array}{c}\text { Rerata Tingkat Kepadatan } \\
\text { Spermatozoa } \pm \text { SD }\end{array}$} \\
\cline { 2 - 5 } & I & II & III & IV & $\Sigma$ & $105,25 \pm 4,03$ \\
\hline Kontrol & 103 & 107 & 101 & 110 & 421 & $115,3 \pm 3,09$ \\
\hline Perlakuan & 117 & 118 & 111 & 115 & 461 & \\
\hline
\end{tabular}

Hasil penelitian menunjukkan bahwa tingkat kepadatan spermatozoa mencit $M$. musculus, L. mengalami peningkatan pada kelompok perlakuan dibandingkan dengan kelompok kontrol. Jumlah keseluruhan spermatozoa pada kelompok kontrol yaitu $421 \times 10^{4}$ $\mathrm{sel} / \mathrm{ml}$ sperma sedangkan pada kelompok perlakuan yaitu $461 \times 10^{4} \mathrm{sel} / \mathrm{ml}$ sperma. Secara statistik dengan $\alpha 0,01$ dan hasil pengamatan menunjukkan bahwa ada pengaruh pemberian nutrisi kerang darah Anadara granosa, L. terhadap tingkat kepadatan spermatozoa mencit $M$. musculus, L. Hal ini disebabkan karena adanya zat yang berperan penting dalam proses pembentukan spermatozoa yang terkandung di dalam kerang darah Anadara granosa, L. yaitu mineral seng ( $\mathrm{Zn})$. Kandungan $\mathrm{Zn}$ yang sangat tinggi pada kerang darah inilah yang berperan dalam proses spermatogenesis dan dapat memperbaiki kualitas sperma. 
Berdasarkan hasil penelitian Ralf Henkel (1999) dalam Word press (2008) menunjukkan bahwa dengan diet rendah seng (2 ppm) selama 20-24 minggu pada tikus menyebabkan rusaknya perkembangan testikular dan berhentinya proses pembentukan sperma. Mineral seng $(\mathrm{Zn})$ adalah mikromineral yang berperan penting dan terlibat dalam fungsi berbagai enzim. $\mathrm{Zn}$ diperlukan untuk mengaktivasi lebih dari 90 enzim di dalam tubuh, salah satunya adalah enzim dehydroxytestosterone (DHT) . Mekanisme kerja hormon testosteron setelah diaktifkan oleh enzim DHT menurut Soeharso (2004) adalah sel Leydig mensintesis testosteron sesuai dengan tingkat konsentrasi kebutuhannya dalam proses sirkulasi. Laju sintesis dan konsentrasi hormon dalam proses sirkulasi diatur oleh aktivitas sel yang mensintesisnya di bawah kontrol gonadotropin. Testosteron disintesis dari kolesterol yang sebagian besar diambil dari kolesterol LDL. Sintesis testosteron dimulai dengan hidrolisis ester kolesterol dan distribusi kolesterol ke mitokondria. Di dalam mitokondria, kolesterol desmolase mengubah kolesterol menjadi pregnenolon. Pregnenolon kemudian diubah menjadi hormon steroid oleh sitokrom P-450 yang merupakan bagian dari desmolase kompleks. Di dalam sel target, testosteron direduksi menjadi 5 - $\alpha$-dihidrotestosteron (androgen) yang mempunyai potensi androgenik lebih baik.

Setelah pemberian nutrisi kerang darah pada mencit selama 21 hari, terjadi pula perbedaan yang signifikanan terhadap berat epididimis dan berat badan mencit. Asupan kerang darah secara terus-menerus yang kaya akan $\mathrm{Zn}$ akan mensintesis enzim dehydroxytestosterone (DHT) untuk mengaktifkan hormon steroid, yaitu testosteron, yang kemudian di dalam sel target, testosteron mengalami reduksi oleh 5 - $\alpha$-dihidrotestosteron menjadi androgen. Penelitian Prasad (1973-1974) dan Suhadi (1979) dalam Word press (2008) menyatakan bahwa pematangan spermatozoa dalam epididimis akan terganggu jika kadar androgen rendah. Ternyata ambang kadar androgen yang diperlukan epididimis lebih tinggi daripada yang diperlukan testis. Oleh karena itu epididimis mencit yang diberi nutrisi kerang darah lebih berat daripada mencit yang tidak diberi kerang darah (kontrol).

Nutrisi makro pada kerang meliputi karbohidrat $(6,01 \mathrm{~g} / 100 \mathrm{~g})$, protein $(17,1 \mathrm{~g} / 100 \mathrm{~g})$, dan lemak $(0,76 \mathrm{~g} / 100 \mathrm{~g})$. Mineral seperti $\mathrm{Zn}$ dan $\mathrm{Ca}$ sangat berperan dalam spermatogenesis. Kerang sangat kaya akan Zn, Fe dan Cu sedangkan kadar kalsiumnya lebih tinggi dibandingkan dengan yang terdapat pada daging dan ikan. Diduga kandungan kerang atas mineral-mineral yang sangat tinggi dapat memperbaiki kualitas spermatozoa (Piggot, 1990). Selain itu, kerang mengandung mineral esensial yang membantu bekerjanya lebih dari 70 macam enzim, hormon, dan proses biosintesa dalam tubuh (Harly, 2003).

\section{Kesimpulan}

Berdasarkan hasil penelitian disimpulkan bahwa pemberian nutrisi kerang darah Anadara granosa $\mathrm{L}$. berpengaruh terhadap penambahan tingkat kepadatan spermatozoa mencit Mus musculus L. (Uji statistik "F" $\alpha 0,01=13,74$ ). 


\section{Daftar Pustaka}

Adelman, M.M., dan Eileen M.C. 1989. Atlas of Sperm Morphology. American Society of Clinical Pathologist, Chicago. USA.

Adnan. 2004. Struktur dan Perkembangan Hewan. Jurusan Biologi FMIPA UNM. Makassar.

Furkon, U.A. 2012. Konsumsi Kerang dan Udang. http://multiply.com/info/com

Halim. 2006. Nutrisi Makro dan Mikro. http://revell-indonesia.com/id=susybastians

Harly. 2003. Kerang dan Udang Aman. http://cyberman.cbn.net.id/cbprt/common/ banner.aspx

Jeyendran, R.S. 2000. Interpretation of Semen Analyses Results : A Practical Guide. Cambridge University Press. UK.

Lewis. 1996. Effect of Sperm Activity on Zinc and Fructose Concentration in Seminal Plasma. http://vlpt.bebas-blogup.htm

Malole, M.B.M., dkk. 1989. Penggunaan Hewan-Hewan Percobaan di Laboratorium. IPB. Bogor.

Nontji, A. 2002. Laut Nusantara. Penerbit Djambatan. Jakarta.

Pigott, G.M., dan Barbee W.T. 1990. Effect of Technology on Nutrition. Marcell Dekker. New York.

Soeharso, P. 2004. Biology Molecular in Reproduction Hormon. Majalah Kedokteran Indonesia. http://embriology.med/unsw.edu/sw.com

Suwignyo, dkk. 2005. Avertebrata Air, jilid 1. Penerbit Swadaya. Jakarta.

World Health Organization. 1999. WHO Laboratory Manual for the Examination of Human Semen and Semen-Cervical Mucus Interaction, edisi ke-4. Cambridge University Press. UK. 